Agro-Science Journal of Tropical Agriculture, Food, Environment and Extension Volume 15 Number 1 January, 2016 pp. 34-38

ISSN 1119-7455

\title{
THE EFFECT OF REPLACING SOYA BEAN MEAL WITH COOKED Mucuna sloanei MEAL ON GROWTH PERFORMANCE, CARCASS CHARACTERISTICS AND BLOOD INDICES OF BROILER FINISHERS
}

\author{
Esiegwu*, A.C. \\ Department of Animal Science \& Fisheries, Imo State University, P.M.B. 2000 Owerri - Nigeria \\ *Corresponding author's email: arthuresiegwu@yahoo.com
}

\begin{abstract}
The experiment was conducted to determine the effect of cooked Mucuna sloanei meal (CMSM) on growth performance, carcass characteristics and blood indices of finisher broilers. Mucuna sloanei seeds were processed into meal and analyzed for proximate and phytochemical compositions. The meal was then used to make four broiler finisher diets at 0, 5.0, 10.0 and 15.0\% inclusion levels respectively. Each diet was fed to a group of 30 finisher broilers at 5 weeks old for 28 days, using completely randomized design. Each group was further subdivided into three replicates of 10 birds each. There were no treatments effects $(p>0.05)$ on the average daily body weight gain, average daily feed intake and feed conversion ratio. Cost of production increased as the dietary level of CMSM increased. The organ weight (liver, heart and gizzard) were not affected by treatments $(p>0.05)$. The carcass characteristics did not show any treatment effect $(p>0.05)$ for all the parameters measured including dressed weight, breast weight, drum stick, wing, length of intestine etc. Heametologically, only the haemoglobin and red blood cell were significantly decreased $(p<0.05)$ at $15 \%$ dietary level. Other parameters such as the packed cell volume, white blood cell, mean cell volume, mean cell haemoglobin, mean cell haemoglobin concentration did not show any significant difference $(p>0.05)$. Biochemical indices show that the serum protein and serum creatinine were significantly decreased $(p<$ 0.05 ) at $15.0 \%$ dietary level. The enzymes (alanine amino transaminase, serum glutamate oxaloacetate transaminase and serum glutamate pyruvate transaminase) did not show any significant difference ( $p>$ 0.05). It was therefore concluded that 5\% inclusion levels of CMSM in the ration of broilers finishers will yield optimum production.
\end{abstract}

Key words: blood indices, broilers, carcass, cooked Mucuna, growth performance

\section{INTRODUCTION}

Soya bean (Glycin max) is an oil seed legume that is rich in protein and used for both human and animal feeding and for industrial purposes. It is the major source of protein for non-ruminant feeding, constituting about $20-30 \%$ level of inclusion in poultry ration (Opara and Okorie, 2015). The over dependence on soya bean as major protein source for monogastric animal feeding and for human and industrial purposes has increased its scarcity and consequently leading to high cost of production. In the light of the above, it has become necessary to investigate into some leguminous seeds that are rich in protein, available and affordable that can replace soya bean either partially or wholly as a protein source. Mucuna sloanei is one legume that has such a potential. Mucuna sloanei seeds are used in South Eastern part of Nigeria as condiment and for thickening of soup. It yields about 0.8-2 tonnes of seeds per hectare with crude protein of about 28\% (Aduku, 1993, Ijeh et al., 2004). Uzomah and Odusanya (2011) reported $23.92 \%$ crude protein, $3.18 \%$ crude fibre, $6.57 \%$ ether extract, $1.96 \%$ ash and $55.19 \%$ carbohydrate for Mucuna sloanei. Igbabul et al. (2012) reported that 48-h fermented Mucuna sloanei contains $32.82 \%$ crude protein, $8.6 \%$ crude fat, $1.0 \%$ crude fibre, $1.0 \%$ ash and $51.59 \%$ carbohydrate. Whereas Akinmutimi et al., (2011) reported a crude protein of $28.96 \%$, crude fat $(5.61 \%)$, crude fibre $(8.11 \%)$, ash $(4.55 \%)$, nitrogen free extract $(28.55 \%)$ and gross energy $(3.94 \mathrm{kcal} / \mathrm{g})$ for toasted Mucuna sloanei. One of the major limiting factors of legume utilization is the presence of anti-nutritional factors (Oke et al., 2002).

Similar to other leguminous grains, Mucuna seeds possess anti-nutritional factors such as Ldihydroxyphenylalanine, tannins, trypsin inhibitors etc. (Ukachukwu and Obioha 1997, Akinmutimi and Okwu, 2006). Akinmutimi et al. (2011) reported that Mucuna sloanei contains Ldihydroxyphenylalanine $(3.61 \%)$, tannin $(0.17 \%)$ and hydrogen cyanide $(8.27 \%)$. There is therefore, the need to process the seed in order to reduce or completely eliminate some or all of the antinutrients before use for efficient utilization of the nutrients. Therefore, cooking is one of the most effective means of detoxifying feed ingredients. 
Ukachukwu and Obioha (1997) recommended detoxification by cooking for 90 minutes or toasting for 60 minutes. This study therefore was aimed at investigating the effect of cooked Mucuna sloanei meal on the growth performance, carcass characteristic and blood indices of finisher broilers.

\section{MATERIALS AND METHODS Study Area}

The experiment was carried out in the teaching and research farm of Imo State University, Owerri. Owerri lies between latitudes $5^{\circ} 35^{\prime} \mathrm{N}$ and $6^{\circ} 10^{\prime} \mathrm{N}$ and longitudes $6^{\circ} 40^{\prime} \mathrm{E}$ and $7^{\circ} 11^{\prime} \mathrm{E}$ at $90 \mathrm{~m}$ above sea level. It has an annual mean temperature of $32.18^{\circ} \mathrm{C}$ and annual rainfall of $192-194 \mathrm{~cm}$ with a relative humidity of 77-78.42\% annually (Federal Ministry of Aviation, Atlas of Imo State, 1984).

\section{Source and Processing Of Mucuna Sloanei}

The Mucuna sloanei seeds were bought from a reputable source in Afor Oru market in Ahiazu Mbaise LGA of Imo State. The seeds were cracked, dehulled, soaked in water overnight and cooked in water for 60 minitues. Thereafter, the seeds were dried in the sun for 7 days. It was then ground into fine powdery Mucuna sloanei meal which was subjected to proximate analysis according to AOAC (2010).

\section{Experimental Diets}

Four finisher broiler diets were compounded, incorporating cooked Mucuna sloanei meal (CMSM) at 0, 5.0, 10.0 and $15.0 \%$ inclusion levels respectively partly replacing soya bean in the control diet. The diets were thus designated as $\mathrm{T}_{0}$, $\mathrm{T}_{5.0}, \mathrm{~T}_{10.0}$ and $\mathrm{T}_{15.0}$, respectively. The ingredient and calculated nutrient composition of the diets are shown in Table 1.

\section{Experimental Birds and Designs}

One hundred and twenty (120) delight super strain broiler chicks bought from a reputable dealer in Owerri were used for the trial. The birds were randomly divided into four groups of 30 broilers and each group randomly assigned to one of the four treatment diets in a completely randomized design (CRD). Each group was further subdivided into 3 replicates of 10 birds per replicate and each replicate housed in a deep litter compartment measuring $1 \mathrm{~m} \times 1.5 \mathrm{~m}$. Feed and water were provided ad libitum. The trial lasted for 28 days.

\section{Data Collection and Analysis}

The birds were weighed at the beginning of the experiment to obtain their initial body weights and then weekly thereafter. Daily feed intake was determined by subtracting the weight of leftover feed from the weight of the feed given the previous day. Data collected included initial body weight, weekly body weight, final body weight and daily feed intake. Feed conversion ratio was calculated by dividing the average daily feed intake by the average daily weight gain.

\section{Carcass Evaluation}

At the end of the feeding trial, three birds were randomly selected from each treatment (one per replicate) and used for evaluation of carcass and internal organ weights. The birds were starved of feed overnight and then slaughtered by severing the jugular vein with sharp knife after they have been weighed. The birds were defeathered and eviscerated. The live weights and dressed weights were recorded and the internal organ (liver, kidney, heart, gizzard and intestine) were recorded and expressed as percentage of live weight.

\section{Haematology and Blood Biochemistry}

At the end of the 28 days feeding trial, 5-ml blood samples were collected from three birds from each treatment and placed in the specimen bottles with and without Ethylene Diamine Tetra Acetic Acid (EDTA) for haematological and blood biochemical evaluation, respectively according to Monica (1984).

\section{Statistical Analysis}

Data collected were subjected to one-way analysis of variance (Snedecor and Cochran 1978) where analysis of variance indicated significant treatment effects; means were compared using Duncan's New Multiple Range Test (DNMRT) as outlined by Obi (1990).

Table 1: Ingredient and calculated chemical composition of the experimental diets

\begin{tabular}{|c|c|c|c|c|}
\hline \multirow[b]{2}{*}{ Ingredients } & \multicolumn{4}{|c|}{ Dietary level of CMSM } \\
\hline & T0 & T5.0 & T10.0 & T15.0 \\
\hline Maize & 55 & 55 & 55 & 55 \\
\hline Cooked Mucuna meal & 0 & 5 & 10 & 15 \\
\hline Soya bean meal & 15 & 10 & 5 & 0 \\
\hline Groundnut cake & 3 & 3 & 3 & 3 \\
\hline Fish meal & 3 & 3 & 3 & 3 \\
\hline Blood meal & 2 & 2 & 2 & 2 \\
\hline Palm kernel cake & 7 & 7 & 7 & 7 \\
\hline Brewer's dried grain & 9 & 9 & 9 & 9 \\
\hline Bone meal & 5 & 5 & 5 & 5 \\
\hline Salt & 0.25 & 0.25 & 0.25 & 0.25 \\
\hline *Vitamin premix & 0.25 & 0.25 & 0.25 & 0.25 \\
\hline L-lysine & 0.30 & 0.30 & 0.30 & 0.30 \\
\hline DL-methionine & 0.20 & 0.20 & 0.20 & 0.20 \\
\hline \multicolumn{5}{|c|}{ Calculated chemical composition (\% DM) } \\
\hline Crude protein & 20.12 & 18.95 & 17.79 & 16.62 \\
\hline Crude fibre & 4.62 & 4.93 & 5.25 & 5.55 \\
\hline Ether extract & 4.44 & 4.79 & 5.16 & 5.52 \\
\hline Calcium & 0.19 & 0.18 & 0.17 & 0.16 \\
\hline Phosphorus & 0.49 & 0.46 & 0.43 & 0.37 \\
\hline Lysine & 0.97 & 0.83 & 0.70 & 0.56 \\
\hline Methionine & 0.38 & 0.35 & 0.32 & 0.29 \\
\hline $\mathrm{ME}(\mathrm{kcal} / \mathrm{kg})$ & 2888.33 & 2926.90 & 2965.48 & 3004.05 \\
\hline
\end{tabular}


Table 2: Proximate and phytochemical composition of cooked Mucuna sloanei meal

\begin{tabular}{lc}
\hline Constituents & Amount $\mathrm{mg} / 100 \mathrm{~g}(\% \mathrm{DM})$ \\
\hline Crude protein & 20.65 \\
Ether extracts & 10.82 \\
Crude fibre & 12.76 \\
Ash content & 3.25 \\
Nitrogen free extract & 43.69 \\
ME (kcal/kg) & 3191.47 \\
Phytochemical composition & \\
Tannins & 29.25 \\
Saponnins & 3.40 \\
Alkaloids & 6.03 \\
Flavonoids & 8.94 \\
Cardiac glycosides & 8.13 \\
Phytate & 0.66 \\
Phenol & 0.110 \\
\hline
\end{tabular}

\section{RESULTS AND DISCUSSION \\ Proximate Composition}

The proximate composition and phytochemical composition of cooked Mucuna sloanei meal (CMSM) are shown in Table 2. The crude protein content and nitrogen free extract were similar to the report of Akpata and Miachi (2001) and Opara and Okorie (2015). Table 2 shows some anti-nutritional factors present in CMSM implying that cooking does not completely remove these toxic elements from the seed.

\section{Performance of Finisher Broilers}

The performance of the experimental finisher broilers is shown in Table 3. The growth performance table shows that there were no significant differences $(p>0.05)$ in the average daily body weight gain, average daily feed intake and feed conversion ratio for all the various dietary treatments. This is similar to the report of Opara and Okorie (2015). This non-significant difference implies that Mucuna sloanei could serve as an alternative to soya bean at these levels without any deleterious effect. However, 5\% dietary level gave better performance for average daily weight gain feed conversion ratio and cost effectiveness relative to other Mucuna dietary levels. Feed intake was depressed at $15 \%$ dietary levels.

The cost effectiveness of using Mucuna sloanei as a substitute to soya bean in broiler production showed that feed cost increased at $111.00 \%, 182 \%$ and $210 \%$ as the dietary level of CMSM increased. However, cost of any feed ingredient depends on the availability of the ingredients, season and the forces of demand and supply.

\section{Carcass Characteristics}

The internal organ weights are shown in Table 4. There were no treatment effects $(p>0.05)$ on the liver and heart ( $\%$ of live weight). This implies that the CMSM did not cause any harm or damage to the organs. There were no treatment effect ( $p>$ 0.05 ) on the percent dressed weight, breast muscle, wing, shank and drumstick as shown in the Table 4.

\section{Haemetology and Blood Biochemistry}

The haemetological and blood biochemical indices of broilers fed CMSM are shown in Table 5. The haemoglobin and RBC were significantly decreased ( $\mathrm{p}<0.05)$ at $15 \%$ dietary level. Reduction in the values of haemoglobin and red blood cell (RBC) could be signs of anaemia (Mohammed and Oloyede, 2009) and may also be a pointer to congenital heart disease, lung disease, dehydration and kidney disease (Odoemelam et al., 2014). There were no treatment effects on the packed cell volume (PCV) for all the various dietary levels and the values were within the range recommended by Siegmum (1979). It means that the cooking process was able to detoxify the antinutrients to the extent that allowed proper nutrient utilization for red blood formation. The white blood cell (WBC), mean cell volume (MCV), mean cell haemoglobin $(\mathrm{MCH})$ and meaqn cell haemoglobin concentration (MCHC) were statistically similar $(\mathrm{p}>0.05)$. This was an indication of no infection or toxin injection into the blood stream as a result of the detoxifying action of the cooking process.

Total protein and creatinine were significantly decreased at $15 \%$ dietary levels. Serum protein has been implicated as a pointer to strong amino acid metabolism (Shulkla and Pachaurii 1995). Decreased serum protein concentration is an indication of alteration of normal protein metabolism due to interference of protein utilization (Bolu and Balogun, 2009).

Increased serum creatinine has been reported to be due to metabolism of muscle protein and indicative of increased protein degradation enzymes arginase, orinithine, trascarbamilase responsible for regulating creatinine levels (Bolu and Balogun, 2009). Low value of creatinine indicates no muscle wastage. The decreased value of creatinine obtained in this study indicates that

Table 3: Performance of experimental finisher broilers

\begin{tabular}{|c|c|c|c|c|c|}
\hline \multirow[b]{2}{*}{ Parameters } & \multicolumn{5}{|c|}{ Dietary levels of CMSM } \\
\hline & $\mathrm{T}_{0.0}$ & $\mathrm{~T}_{5.0}$ & $\mathrm{~T}_{10.0}$ & $\mathrm{~T}_{15.0}$ & SEM \\
\hline Average initial weight (g) & 1062.67 & 1073.33 & 1026.67 & 1063.33 & 48.8 \\
\hline Average final body weight $(\mathrm{g})$ & 2167.00 & 233.00 & 2011.00 & 1900.00 & 188 \\
\hline Average daily body weight gain (g) & 39.44 & 44.99 & 35.15 & 29.88 & 6.2 \\
\hline Average daily feed intake (g) & 102.04 & 108.63 & 108.93 & 86.63 & 9.1 \\
\hline Feed conversion ratio & 2.59 & 2.41 & 3.10 & 2.90 & 0.6 \\
\hline Feed cost $(\mathbb{N} / \mathrm{kg}$ feed $)$ & 111.48 & 133.06 & 169.04 & 209.74 & \\
\hline Cost of feed per kg weight & 288.73 & 320.67 & 525.71 & 608.25 & \\
\hline
\end{tabular}


The Effect of Replacing Soya Bean Meal with Cooked Mucuna sloanei Meal on Growth Performance, Carcass Characteristics and Blood Indices of Broiler Finishers

Table 4: Results of the carcass and organ characteristics of finisher broiler birds fed CMSM (\% Live Weight)

\begin{tabular}{|c|c|c|c|c|c|}
\hline \multirow[b]{2}{*}{ Parameter } & \multicolumn{5}{|c|}{ \% Dietary Treatment } \\
\hline & $\mathrm{T}_{0}$ & $\mathrm{~T}_{5.0}$ & $\mathrm{~T}_{10.0}$ & $\mathrm{~T}_{15.0}$ & SEM \\
\hline Live weight (g) & 1923.3 & 2056.7 & 2016.7 & 1800 & 114 \\
\hline Dressed weight (g) & 1410 & 1433 & 1556.7 & 1240 & 105.8 \\
\hline Dressed (\%) & 73.27 & 69.37 & 77.17 & 68.70 & 0.82 \\
\hline Breast (\%) & 18.13 & 15.97 & 17.13 & 15.8 & 1.15 \\
\hline Drumstick (\%) & 23 & 22 & 20 & 21 & 1.1 \\
\hline $\operatorname{Back}(\%)$ & 8.3 & 10.3 & 8.4 & 7.97 & 0.6 \\
\hline Wing $(\%)$ & 8.2 & 8.1 & 8.6 & 9.4 & 0.3 \\
\hline Waist (\%) & 5.4 & 6 & 6.3 & 5.2 & 0.7 \\
\hline $\operatorname{Neck}(\%)$ & 5 & 3.3 & 4.4 & 4.7 & 0.46 \\
\hline Vent $(\%)$ & $5^{\mathrm{ac}}$ & $4.7^{\mathrm{bc}}$ & $6.2^{\mathrm{a}}$ & $4.4^{\mathrm{bc}}$ & 0.4 \\
\hline Head $(\%)$ & 2.4 & 2.8 & 3.2 & 3.3 & 0.36 \\
\hline Shank (\%) & 3.9 & 4.8 & 4.2 & 4.6 & 0.2 \\
\hline Gizzard (\%) & 3.1 & 2.8 & 3.7 & 3.2 & 0.48 \\
\hline Liver (\%) & 2.8 & 2.77 & 2.57 & 2.4 & 0.35 \\
\hline Heart $(\%)$ & 0.95 & 0.96 & 1.3 & 1.2 & 0.16 \\
\hline Intestine & 184 & 196 & 185 & 183 & 6.9 \\
\hline
\end{tabular}

Table 5: Haematological indices of finisher broilers fed cooked Mucuna sloanei seed meal

\begin{tabular}{|c|c|c|c|c|c|}
\hline \multirow[b]{2}{*}{ Parameters } & \multicolumn{4}{|c|}{ Dietary level of CMSM } & \multirow[b]{2}{*}{ SEM } \\
\hline & $\mathrm{T}_{0}$ & $\mathrm{~T}_{5.0}$ & $\mathrm{~T}_{10.0}$ & $\mathrm{~T}_{15.0}$ & \\
\hline Haemoglobin (g/dl) & $13^{\mathrm{a}}$ & $12.8^{\mathrm{a}}$ & $12.4^{\mathrm{ac}}$ & $11.97^{\mathrm{c}}$ & 0.26 \\
\hline PCV\% & 42 & 41 & 39 & 36.67 & 1.7 \\
\hline $\mathrm{RBC}\left(\times 10^{6}\right)$ & $13.1^{\mathrm{a}}$ & $12.8^{\mathrm{a}}$ & $12.4^{\mathrm{ac}}$ & $11.9^{\mathrm{c}}$ & 0.26 \\
\hline $\mathrm{WBC}\left(\times 10^{3 / 1}\right)$ & 11.57 & 11.37 & 11.33 & 11.37 & 0.19 \\
\hline \multicolumn{6}{|l|}{ WBC differential } \\
\hline Neutrophilis \% & 54.3 & 51.67 & 51.67 & 53.3 & 0.88 \\
\hline Eosinophilis \% & 1.67 & 1.3 & 1.67 & 1.3 & 0.33 \\
\hline Basophilis \% & 0 & 0 & 0 & 0 & 0 \\
\hline Lymphocytes \% & 42.67 & 45.33 & 45.33 & 44 & 11 \\
\hline Monocyte \% & 1.33 & 1.67 & 1.33 & 1.33 & 1.1 \\
\hline ESR-MM/Ist & 14.67 & 16 & 17.7 & 17 & 1.4 \\
\hline $\operatorname{MCV}\left(\mathrm{UM}^{3}\right)$ & 31.63 & 32.43 & 32.70 & 31.90 & 0.69 \\
\hline $\mathrm{MCH}\left(\mathrm{UM}^{3}\right)$ & 9.9 & 10 & 10 & 10 & 1.8 \\
\hline $\operatorname{MCHC}(\%)$ & 9.9 & 10.2 & 10.1 & 10 & 0.65 \\
\hline \multicolumn{6}{|l|}{ Biochemical indices } \\
\hline Total protein $(\mathrm{g} / \mathrm{l})$ & $64^{\mathrm{a}}$ & $60.33^{\mathrm{a}}$ & $56.7^{\mathrm{ab}}$ & $54.7^{\mathrm{b}}$ & 1.5 \\
\hline Albumin (g/dl) & 22.67 & 20.67 & 21.33 & 20.67 & 0.88 \\
\hline Globulin (g/dl) & $41.33^{\mathrm{a}}$ & $39.67^{\mathrm{ab}}$ & $35.33^{\mathrm{c}}$ & $34^{\mathrm{c}}$ & 1.96 \\
\hline Uric acid (mg/dl) & 9 & 8.6 & 8.4 & 7.8 & 0.11 \\
\hline Creatinine (mg/dl) & $24.67 \mathrm{a}$ & $22.67^{\mathrm{a}}$ & $21.67^{\mathrm{ab}}$ & $21 b$ & 0.82 \\
\hline Cholesterol (mg/dl) & 10.3 & 10.1 & 9.7 & 9.4 & 0.11 \\
\hline $\operatorname{ALT}(\mathrm{IU} / \mathrm{L})$ & 1.33 & 1.27 & 1.17 & 1.17 & 0.08 \\
\hline SGOT (IU/L) & 11.83 & 11.63 & 11.87 & 11.33 & 0.21 \\
\hline SGPT (IU/L) & 7.23 & 7.06 & 6.9 & 6.9 & 0.19 \\
\hline Sodium $\mathrm{Na}+$ & $44^{\mathrm{a}}$ & $41.3^{\mathrm{ab}}$ & $39.3^{\mathrm{b}}$ & $38.7^{\mathrm{b}}$ & 0.88 \\
\hline Potassium K+ & $1.4^{\mathrm{a}}$ & $1.27^{\mathrm{a}}$ & $1.0^{\mathrm{ab}}$ & $0.97^{\mathrm{b}}$ & 0.1 \\
\hline $\mathrm{Hco}_{3}^{-}$ & $11.07^{\mathrm{a}}$ & $10.8^{\mathrm{a}}$ & $10.3^{\mathrm{b}}$ & $10.27^{\mathrm{b}}$ & 0.13 \\
\hline Chlorine CL & $25.7^{\mathrm{a}}$ & $22^{\mathrm{b}}$ & $20.7^{\mathrm{b}}$ & $20.3^{\mathrm{b}}$ & 1.0 \\
\hline
\end{tabular}

there was no muscle wastage (Ukpabi et al., 2015). Serum enzymes activities are used for checking toxicity as well as monitoring protein quality (Ukpabi et al., 2015). The enzymes, serum alkaline phosphatase (ALP), serum glutamic oxaloacetic transaminase (SGOT) and serum glutamic pyruvic transaminase (SGPT) were statistically similar for all the different dietary treatments. This indicates that there was no poisoning of the blood of the broiler by the use of cooked Mucuna sloanei meal.

\section{CONCLUSION}

The results of the trial showed that cooked Mucuna sloanei meal can serve as a replacement to soya bean meal in broiler finisher diet at 5\% level. Beyond 5\% level, the average daily weight gain decreases and feed conversion ratio increases. Inclusion of cooked Mucuna sloanei meal in the diet of broiler finisher birds had no effect on the carcass, haematology and blood biochemistry of broiler finishers. It is therefore concluded that for optimal broiler growth, 5\% dietary levels of cooked Mucuna sloanei meal is recommended. 


\section{REFERENCES}

Aduku, A.O. (1993). Tropical feedstuff analysis table. Department of Animal Science, Ahmadu Bello University, Samaru Zaria, Kaduna State, Nigeria

Akinmutimi, A.H. and Okwu, N.D. (2006). Effect of quantitative substitution of cooked Mucuna utilis seed meal for soya bean meal in broiler finisher diet. Int. Journal of Poultry Science. 5 (5), 477-481

Akinmutimi, A.H., Edet, J.D., Okocha, C.N. and Odoemelam, V.N. (2011). The evaluation of toasted Mucuna sloanei meal as a feed ingredient in broiler diet. International Journal of Current Research, 3 (4), 120-126

Akpata, A.O. and Miachi, E.U. (2001). Chemical composition and selected functional properties of sweet orange and legumes, flours, plant food. Human Nutrition, 54, 353-362

AOAC (2010). Association of Official Analytical Chemists. Official Methods of Analysis, $19^{\text {th }}$ edition, Washington D. C. USA

Atlas of Imo State, Nigeria (1984) Government press.

Bolu, S.A. and Balogun, O.O. (2009). Effects of improved (addition of antimicrobials and antioxidants) locally produced natural vitamin premix on performance, haematology and some serum constituents of broiler chickens. Nig. J. Anim. Prod. 36 (2), 246-255

Igbabul, B.D., Idikwu, H.O. and Inyang C.U. (2012). Effect of fermentation on some functional properties of Mucuna sloanei and Detarium microcarpum. Journal of Food Technology. 10 (3), 83-86

Ijeh, I.I., Unaegbu, S.O. and Anaga, A.O. (2004). Studies on some nutritional and toxicological properties of Mucuna sloanei. African Journal online Bioresearch. 2(1), 24-28

Mohammed, N.O. and Oloyede, O.B. (2009). Growth performance of broiler chicks fed Aspergillus nigerfermented Terminalia catappa seed meal based diet. Global Journal of Biotechnology \& Biochemistry. 4(2), 179-183

Monica, C. (1984). Medical laboratory manual for tropical countries. Vol. 11. Microbiology ELBS Ed.
Obi, I.U. (1990). Statistical Methods of Detecting Differences between Treatment means. $2^{\text {nd }}$ edition, Snap press, Enugu, Nigeria

Odoemelam, V.U., Ndelekwute, E.K., Igbonaeme, U.J. and Ogbuewe, I.P. (2014). Comparative effect of basil leaf (Ocimum gratissimum) meal and antibiotic growth promoter (oxytetracycline HCL) and heamotology and biochemical indices of broiler chickens. Nigerian Journal of Animal Science. 16 (2): 235-243

Oke, D.B., Oke, M.O. and Adeyemi, O.A. (2002). Predictions of cowpea seed protein quality through total sulphure determination. Proceedings of $7^{\text {th }}$ Annual Conference of Animal Science Association of Nigeria Sept. 16-19 ${ }^{\text {th }}, 2002$. p. 121

Opara, A.U. and Okorie, K.C. (2015). Effect of cooked Mucuna sloanei seed meal on the performance, carcass characteristics and apparent nutrient digestibility on broiler finisher birds. International Journal of Agricultural Bioscience. 4(4): 145-149

Shukla, S.K. and Pachaurii, S.P. (1995). Blood biochemical profiles in induced aflatoxicosis of cockerels. British Poultry Science. 36: 1545-1560

Siegmum, O.H. (1979). Editor Veterinary Manual. 13 ${ }^{\text {th }}$ edition, $21 \mathrm{p}$.

Snedeccor, C.W. and Cochran, W.G. (1978). Statistical methods. The IOWA State University press, AmesIOWA, $6^{\text {th }}$ Edition

Ukachukwu, S.N. and Obioha, F.C. (1997). Chemical evaluation of Mucuna conchichinonsis as alternative protein feedstuff. Journal of Applied Chemistry \& Agricultural Research, 4, 33-38

Ukpabi, U.H., Mbachu, C.L. and Nwazue, B. (2015). Effect of inclusion of different levels of Raw Adenanthera pavanina Seed Meal (RAPSM) on haematology and blood chemistry of finisher broilers. Nigeria Journal of Animal Science. 17 (1), 28-36

Uzomah, A. and Odusanya, O.S (2011). Mucuna sloanei, Detarium microcarpum and Brachystegia eurycoma seeds: a preliminary study of their starch hydrocolloids system. African Journal of Food Science, 5 (13), 733-740 